\title{
Cattle Grazing Blue Grama Rangeland II. Seasonal Forage Intake and Digesta Kinetics
}

\section{F.T. MCCOLLUM AND M.L. GALYEAN}

\begin{abstract}
Four field trials were conducted from early August to late October, 1982, on blue grama (Bouteloua gracilis) rangeland in south-central New Mexico, to examine relationships among grazing season, forage intake and digestive function in beef steers (Bos taurus). Organic matter intake declined from $24.0 \mathrm{~g} / \mathrm{kg}$ body weight (BW) in early August to $17.4 \mathrm{~g} / \mathrm{kg}$ BW in late September and then increased to $20.9 \mathrm{~g} / \mathrm{kg} \mathrm{BW}$ in the early dormant season (late October). From early growing season to early dormancy, diet digestibility and passage rates decreased while retention time of digesta in the rumen increased. Rate and extent of in vitro organic matter disappearance were $66.5,6.7 ; 63.1,6.7 ; 51.6,4.8$; and $47.9 \%$, $5.6 \%$ /hour in early August, late August, late September and late October, respectively. Fluid and particulate passage rates (\%/hour) were $24.9,4.6 ; 12.7,3.9 ; 11.1,3.7 ;$ and $10.5,3.5$, respectively, for the same periods. Retention of particulate digesta varied from 26.1 hours in the early growing season to 34.3 hours in early dormancy. Gastrointestinal fill gradually increased as season progressed. Results suggest that maintenance of a diverse plant community, containing not only desirable grasses but also palatable forbs, may allow cattle to maintain a higher level of nutrient intake during periods of grass dormancy.
\end{abstract}

Livestock production from rangelands may be limited by a number of factors. Ignoring managerial capabilities, the greatest limits are possibly those related to the grazing animal's ability to select and consume a diet supplying enough nutrients to meet daily requirements for maintenance and production. A better understanding of factors that interact to determine the quantity of nutrients consumed daily might allow range-livestock managers to manipulate the grazing environment and enhance the nutritional status of the grazer.

Disappearance of digesta from the gastrointestinal tract of ruminants is a function of the competing processes of digestion and passage of undigested residues (Van Soest 1982). Studies directed toward evaluation of rates of digesta passage in ruminants grazing

At the time of the research, authors were graduate assistant and associate professor, respectively, Department of Animal and Range Sciences, New Mexico State University. Las Cruces 88003 . McCollum is currently assistant professor, Animal Science Department, Oklahoma State University, Stillwater 74078.

This article is a contribution from New Mexico Agr. Exp. Sta. Journal Article No. 1086.

The authors wish to acknowledge the assistance of Drs. A.L. Goctsch, R.E. Estell, and M.B. Judkins and Harley Segotta.

Manuscript accepted 19 April 1985. native rangelands should provide insight into the mechanisms controlling voluntary intake in such animals. Cordova et al. (1978) reviewed literature on intake by grazing livestock while others (Van Soest 1965; Thornton and Minson 1973) described the influences of forage type on intake. Generally, these reports described a decline in quality and quantity of intake with progressing season and potentially greater intakes of legume-type forages relative to grasses. However, data on the chemical and botanical composition of range diets and associated changes in forage intake by grazing livestock are limited (Holechek and Vavra 1982).

The objectives of this study and another reported previously (McCollum et al. 1985) were to relate changes in diet composition with changes in forage intake and rumen function in beef steers (Bos taurus) grazing native blue grama (Bouteloua gracilis) rangeland over 4 periods of a growing season. This paper discusses the influences of advancing season on forage intake and related changes in rates of passage and digestion of seasonal diets.

\section{Materials and Methods}

\section{Study Area}

All field trials were conducted at the Fort Stanton Experimental Ranch in the foothills between the Sierra Blanca and Capitan mountains in southern Lincoln County, New Mexico. Pieper et al. (1971) described topography, rainfall, and major species of vegetation in the study area.

\section{Field Trials}

Four trials were conducted at various times corresponding to phenological changes in the plant community (9 Aug.-17 Aug., EAug, 27 Aug.-4 Sept., LAug; 23 Sept.-1 Oct., LSept; 23 Oct.-31 Oct., LOct). During each trial, 3 esophageal-cannulated, dry pregnant mature cows and 6 rumen-cannulated steers (Hereford $X$ Angus; weights shown in Table 1) were allowed to freely graze the study pasture. No other animals were grazed on the study pasture during adjustment and sampling periods. Cows were placed on pasture a minimum of 1 week before each trial, while steers were placed on pasture 2 weeks before the EAug trial and grazed continuously through the LOct trial.

Esophageal extrusa samples were collected during the first 2 days of each trial (McCollum et al. 1985). Following the second day of collection, aliquots from each of the 6 masticate samples ( 3 
Table 1. Organic matter intake and fecal output in steers grazing blue grama rangeland during different sampling periods.

\begin{tabular}{|c|c|c|c|c|c|}
\hline \multirow[b]{2}{*}{ Item } & \multicolumn{4}{|c|}{ Sampling period } & \multirow[b]{2}{*}{$\mathbf{S E}$} \\
\hline & EAug & LAug & LSept & LOct & \\
\hline \multirow[t]{2}{*}{ Average steer weight, $\mathrm{kg}$} & 270 & 293 & 307 & 342 & \\
\hline & & \multicolumn{3}{|c|}{ - } & - \\
\hline Organic matter intake & $24.0 \mathrm{a}^{2}$ & $20.1 \mathrm{~b}$ & $17.4 \mathrm{c}$ & $20.9 \mathrm{~b}$ & 0.8 \\
\hline Fecal output & $8.0 \mathrm{a}$ & $7.4 a$ & $8.4 a$ & $10.9 b$ & 0.4 \\
\hline
\end{tabular}

iStandard error of treatment means, $n=6$.

${ }^{2}$ Means in a row followed by different letters different $(P<.05)$.

cows $\times 2$ days) were composited. Remaining portions of each sample were individually frozen in plastic bags for later analysis. Composite samples (about $7 \mathrm{~kg}$ ) were washed once with 28 liters of distilled water and labeled with ytterbium (Yb), a rare earth element. Washed masticate was soaked for 24 hours in 28 liters of a solution containing $2.5 \mathrm{~g} \mathrm{YbCl}_{3} \bullet \mathrm{XH}_{2} \mathrm{O}$ per liter. After soaking, masticate was washed 6 times with distilled water to remove unbound $\mathrm{Yb}$. Labeled forage was divided into 7 portions; 6 portions were used as a marker of particulate passage in the steers, and the remaining portion was stored frozen until analyzed for $\mathbf{Y b}$.

At 0800 hour on day $3,250 \mathrm{ml}$ of whole digesta were removed from the rumen of each steer. Rumen contents were thoroughly mixed prior to sample removal. After sampling, each steer was dosed intraruminally with $200 \mathrm{ml}$ of cobalt ethylenediaminetetraacetic acid (CoEDTA; Uden et al. 1980) as a marker of fluid passage. After dosing, rumen contents were thoroughly handmixed to facilitatc marker equilibration. Steers were allowed to return to normal grazing activities and additional rumen samples were obtained at 4, 8, 12 and 24 hours after dosing the CoEDTA. Sample processing at the various collection times as described by McCollum et al. (1985). To facilitate rumen sampling, temporary pens were erected at the site being grazed during each sampling time.

On day 4 of each trial at 0800 hour, each rumen-cannulated steer was dosed intraruminally with its respective portion of $\mathrm{Yb}$-labeled masticate. The dose was placed adjacent to the cardia. Due to variation in the amount of esophageal masticate collected and $\mathrm{Yb}$ binding capacity, the actual amount of forage and $\mathrm{Yb}$ administered varied among trials. In EAug, LAug, LSept, and LOct, steers were dosed with $120,106,120$, and $126 \mathrm{~g}$ of forage dry matter containing $2.7,2.8,2.7$, and $3.6 \mathrm{~g}$ of $\mathrm{Yb}$. After dosing, steers were released to graze freely and rectal grab samples were collected at $0,4,8,12,16$, $20,24,28,32,36,42,54,60,72,84,96,108$, and 120 hours after dosing. Individual grab samples were identified by steer and collection time and stored frozen. Steers were not penned or moved from the grazing site during sample collection.

\section{Laboratory Procedures}

In vitro digestion analyses followed methods outlined by Tilley and Terry (1963) and Mertens and Loften (1980). Rumen samples were thawed overnight at room temperature, after which $40 \mathrm{ml}$ of fluid was drawn from each sample and centrifuged at $12,000 \times \mathrm{g}$ for 10 minutes. The supernatant fluid was then analyzed for cobalt concentration by atomic absorption spectroscopy using an airacetylene flame. Fecal samples were prepared for $\mathrm{Yb}$ analysis by boiling ash residues in a solution of $25 \% \mathrm{HCl}(\mathrm{v} / \mathrm{v})$. After filtration (Whatman 541) and dilution, this solution was analyzed for Yb by atomic absorption spectroscopy with a nitrous oxide-acetylene flame. Standards were made in solubilized ash from 0 hour collections and all samples and standards contained $2000 \mu \mathrm{g} / \mathrm{ml}$ of $\mathrm{K}$ as an ionization buffer.

\section{Calculations and Statistical Analysis}

Rumen fluid passage rate was calculated by regressing the natural log of Co concentration on time postdosing. Fluid volume was estimated by dividing the dose by estimated concentration at 0 hours. Fecal $\mathrm{Yb}$ concentrations were analyzed by non-linear regression procedures (Marquardt method) of the Statistical Analysis System (Helwig and Council 1979) using a one-compartment model (Pond et al. 1982). Data sets for EAug and LAug failed to fit a two-compartment model (Pond et al. 1982); therefore a one-compartment model was used for all 4 periods. Parameter estimates from the model include tau (calculated time to first appearance of marker in feces), $k_{0}$ (initial concentration of marker in the compartment) and $\mathrm{k}_{1}$ (passage rate constant). Calculations derived from parameter estimates include:

$$
\begin{aligned}
& \text { Flow, } \% / \text { hour }=\left(\mathrm{k}_{1} \bullet .59635\right) \times 100 \\
& \text { Undigested dry matter fill }=\frac{\text { dose }}{\mathrm{k}_{0} \cdot \mathrm{k}_{1} \bullet .59635} \\
& \text { Fecal output } / \text { day }=\frac{\text { dose }}{\mathrm{k}_{0}} \cdot 24 \text { hours } \\
& \text { Mean rumen retention time, hours }=2 / \mathrm{k}_{1} \\
& \text { Intestinal transit time, hours }=\text { tau }
\end{aligned}
$$

Organic matter intake (OMI) was calculated as the ratio of fecal OM output to OM indigestibility, where $O M$ indigestibility was derived from two-stage in vitro digestion.

All data were analyzed as a completely randomized design with effects for season included in the model. Means were separated by the least significant difference method protected by a significant $F$ test.

\section{Results and Discussion}

Estimated voluntary intake (organic matter basis) by the steers averaged $20.6 \mathrm{~g} / \mathrm{kg} \mathrm{BW}$ across the 4 trial periods (Table 1). Intake declined from early to late growing season and then increased from LSept to the early dormancy period (LOct). The steers consumed $16.3,27.5$, and $12.9 \%$ less forage during LAug, LSept and LOct, respectively, than in EAug. An earlier study at Fort Stanton yielded similar OMI estimates for steers grazing in EAug, LAug, and LOct $(21.9,19.5$ and $17.2 \mathrm{~g} \mathrm{OM} / \mathrm{kg} \mathrm{BW}$, respectively; Cordova 1978). Rosiere et al. (1980) reported somewhat lower estimates for cows and heifers grazing in early August ( 17.0 and $12.0 \mathrm{~g} / \mathrm{kg} \mathrm{BW}$ ). At these intake levels, the cattle were consuming $16.0,12.7,9.0$, and $10.0 \mathrm{~g}$ total digestible nutrients (TDN) $/ \mathrm{kg} \mathrm{BW} /$ day and 3.8, 3.0, 1.7 , and $1.6 \mathrm{~g}$ available crude protein (CP)/ $\mathrm{kg} \mathrm{BW} /$ day during EAug, LAug, LSept, and LOct, respectively. Growing steers and heifers, of similar weight to those used in this study and gaining .2 to $.9 \mathrm{~kg} / \mathrm{day}$, require 11.6 to $16.2 \mathrm{~g} \mathrm{TDN} / \mathrm{kg} \mathrm{BW} /$ day and 1.13 to $1.16 \mathrm{~g} \mathrm{CP} / \mathrm{kg} \mathrm{BW} /$ day (NRC 1984). Although available protein intake was s ufficie $\mathrm{nt}$ t h r o u g out the season, energy (TDN) intake would have limited performance in LSept and LOct.

Forage intake was apparently regulated by quality rather than quantity of available forage. Fecal output (FO) was fairly constant across all trial periods (Table 1) indicating that the steers were eating to a constant fill of indigestible residues (Ellis et al. 1984). If forage availability had limited intake, FO would have been depressed. The values reported in Table 1 are well within the range of FO noted in several other studies (Kahn and Spedding 1984). The greater FO in LOct was due either to expanded gut capacity or to the forb component in the diets (McCollum et al. 1985). Kahn and Spedding (1984) proposed that gut capacity will eventually increase in response to prolonged consumption of low quality forage. However, other work suggests that the ease and manner in which legume-type forages (i.e. forbs) fragment during comminution might enable digesta to pack more densely in the digestive tract thereby allowing the animal to accommodate more fill (Ingalls et al. 1966, Troelson and Campbell 1968). Changes in undigested fill (Table 3) and FO (Table 1) support both arguments.

Diet IVOMD declined as season progressed and, with the exception of 4 and 12 hours, time-lapse IVOMD followed a similar 
Table 2. In vitro rate and extent of organic matter disappearance from diets of cattle graxing blue grama rangeland during different sampling periods.

\begin{tabular}{lccccc}
\hline \hline & \multicolumn{5}{c}{ Sampling period } \\
\cline { 2 - 5 } Item & EAug & LAug & LSept & LOct & SE 1 \\
\hline & & & & & \\
IVOMD, inoculum + pepsin & $66.5 \mathrm{a}^{2}$ & $63.1 \mathrm{a}$ & $51.6 \mathrm{~b}$ & $47.9 \mathrm{~b}$ & 2.5 \\
Time lapse OMD, & & & & & \\
4h & $15.0 \mathrm{a}$ & $13.9 \mathrm{~b}$ & $13.1 \mathrm{c}$ & $16.9 \mathrm{~d}$ & 0.2 \\
$12 \mathrm{~h}$ & $19.9 \mathrm{a}$ & $20.6 \mathrm{ab}$ & $17.7 \mathrm{c}$ & $21.8 \mathrm{~b}$ & 0.4 \\
$24 \mathrm{~h}$ & $30.9 \mathrm{a}$ & $31.3 \mathrm{a}$ & $29.0 \mathrm{~b}$ & $27.8 \mathrm{~b}$ & 0.5 \\
36h & $52.2 \mathrm{a}$ & $48.7 \mathrm{~b}$ & $39.3 \mathrm{c}$ & $38.9 \mathrm{c}$ & 0.3 \\
48h & $63.1 \mathrm{a}$ & $57.6 \mathrm{~b}$ & $47.2 \mathrm{c}$ & $48.5 \mathrm{c}$ & 1.2 \\
$72 \mathrm{~h}$ & $64.9 \mathrm{a}$ & $59.4 \mathrm{~b}$ & $51.4 \mathrm{c}$ & $50.5 \mathrm{c}$ & 0.7 \\
Rate of IVOMD, \%/h & 6.7 & 6.7 & 4.8 & 5.6 & 0.7 \\
\hline
\end{tabular}

'Standard error of treatment means, $n=3$.

2Means in a row followed by different letters differ $(\boldsymbol{P <}<05)$.

pattern (Table 2). At 4 hours, the LOct diet had been digested to a greater extent $(P<.05)$ than diets from the earlier trials. However, this advantage disappeared as the incubation period lengthened and, ultimately, LOct diets were not as digestible as diets from the early growing season $(P<.05)$. The early, rapid disappearance of the LOct diet is typical of nongrass plant species. Forb and shrub leaves have much more rapid rates of digestion than grasses (Short et al. 1974, Kothmann 1980). Although there were no statistical differences $(P>.05)$, trends in LSept and LOct suggest that forb consumption was accompanied by a faster rate of digestion. Note that despite a $15 \%$ difference in IVOMD, intake estimates were similar in LAug and LOct while, on the other hand, steers consumed $20 \%$ more OM in LOct than in LSept even through digesility estimates were not different. These paradoxes are possibly related to the early, rapid IVOMD mentioned earlier.

Table 3. Undigested dry matter fill, particulate passage rates and retention times in beef steers grazing blue grama rangeland during different sampling periods.

\begin{tabular}{|c|c|c|c|c|c|}
\hline \multirow[b]{2}{*}{ Item } & \multicolumn{4}{|c|}{ Sampling period } & \multirow[b]{2}{*}{ SE$^{\prime}$} \\
\hline & EAug & LAug & LSept & LOct & \\
\hline $\begin{array}{l}\text { Undigested fill, } \\
\text { g DM/kg BW } \\
\text { Particulate passage }\end{array}$ & $9.7 \mathrm{a}^{2}$ & $12.1 \mathrm{~b}$ & $14.0 \mathrm{c}$ & $17.7 \mathrm{c}$ & 0.5 \\
\hline rate, $\% /$ hour & $4.6 \mathrm{a}$ & $3.9 \mathrm{~b}$ & $3.7 \mathrm{~b}$ & $3.5 \mathrm{~b}$ & 0.1 \\
\hline $\begin{array}{l}\text { Rumen retention time, } \\
\text { hours } \\
\text { Tau, hours }\end{array}$ & $\begin{array}{c}26.1 \mathrm{a} \\
13.6 \mathrm{ab}\end{array}$ & $\begin{array}{l}30.9 b \\
10.6 c\end{array}$ & $\begin{array}{l}32.3 \mathrm{bc} \\
12.8 \mathrm{~b}\end{array}$ & $\begin{array}{l}34.3 \mathrm{c} \\
14.8 \mathrm{a}\end{array}$ & $\begin{array}{l}1.1 \\
0.4\end{array}$ \\
\hline
\end{tabular}

1Standard error of treatment, $n=6$.

${ }^{2}$ Means in a row followed by different letters differ $(P<.05)$.

Particulate flow rates (PFR) (Table 3) were fastest $(P<.05)$ in EAug and tended to slow as season progressed to LOct. The general slowing of PFR in the current study resulted in increasingly longer residence of undigested residue in the rumen and may have contributed to the increases in gut fill noted as the grazing season progressed. Poppi et al. (1980) concluded that reducing the potential exteñt of neutral detergent fiber (NDF) digestion will increase rumen retenticn time and thereby lower intake. Data from EAug through LSept $a_{5}$-ee with this statement; however, from LSept to LOct there was a positive rather than negative relationship between intake and retention time.

From EAug through LÖct, rumen fluid passage rates (FPR) gradually declined from 14.9 to $10.5 \%$ / hour (Table 4). Fluid passage rate was highly correlated $(P<.01)$ with OMI $(r=.65)$ and PFR $(r=.77)$, but it is difficult to determine if these are cause and effect
Table 4. Rumen fluid volume, passage rate, turnover rate and turnover time in beef steers grazing blue grama rangeland during different sampling times.

\begin{tabular}{lccccc}
\hline \hline & \multicolumn{4}{c}{ Sampling period } \\
\cline { 2 - 5 } Item & EAug & LAug & LSept & LOct & SE1 \\
\hline Fluid passage rate, \%/hour & $14.9 \mathrm{a}^{2}$ & $12.7 \mathrm{~b}$ & $11.1 \mathrm{c}$ & $10.5 \mathrm{c}$ & 0.5 \\
Volume, liters/kg BW & $0.11 \mathrm{ab}$ & $0.13 \mathrm{bc}$ & $0.11 \mathrm{a}$ & $0.13 \mathrm{c}$ & 0.01 \\
Turnover rate, liters/hour & $4.3 \mathrm{a}$ & $4.7 \mathrm{a}$ & $3.5 \mathrm{~b}$ & $4.6 \mathrm{a}$ & .2 \\
Turnover time, hours & $6.8 \mathrm{a}$ & $7.9 \mathrm{~b}$ & $9.0 \mathrm{bc}$ & $9.7 \mathrm{c}$ & 0.4 \\
\hline
\end{tabular}

Standard error of treatment means, $n=6$.

${ }_{2}^{2}$ Means in a row followed by different letters differ $(P<.05)$.

relationships. Poppi et al. (1980) suggested ruminal retention time of NDF was dependent on liquid flow from the rumen. But, in another study with sheep, a twofold increase in FPR did not influence PFR (Varga and Prigge 1982). More recently, Owens and Goetsch (1985) proposed that faster liquid flow would remove small particles from the rumen thereby increasing PFR. Seasonal FPR should reflect differences in forage intake, salivation, water intake, and osmotic drag produced by diet components.

Seasonal differences in FPR were reflected in turnover time estimates (Table 4). As noted with particle retention times, advancing season was accompanied by progressively longer fluid turnover times. The ratio of fluid turnover time to particle retention time during each season, was fairly constant $(.26, .26, .28, .28$ for EAug, LAug, LSept, and LOct, respectively) suggesting a possible static relationship between flow of these 2 phases through the gastrointestinal tract (GIT).

\section{Conclusions}

As the season progressed from early to late growing conditions, forage intake declined and the decline was associated with reduced forage digestibility, higher levels of GIT fill, and longer residence time of particulate and fluid digesta phases in the rumen. The combined influences of the factors acted to regulate intake by the grazing steers. But, in early dormancy, forage intake recovered to a level noted in the early growing season. This change can be attributed to increased forb consumption. Dietary forbs apparently benefited forage intake via a more rapid early digestion rate and physical behavior in the gut which allowed the animals to simultaneously increase intake and accommodate more gut fill.

These data suggest that if one desires to increase forage intake, the goal could possibly be accomplished by decreasing lag time prior to active forage degradation in the rumen, or by elevating ruminal capacity or passage rates. Decreasing lag time is plausible as researchers are describing factors and conditions affecting microbial attachment to and breakdown of particles in the rumen. A more desirable long-term goal, as proposed by Grovum (1984), might be to use ruminal volume and passage rates as selection criteria in livestock breeding programs. Finally, maintenance of a diverse plant community, containing not only desirable grasses but also palatable forbs may allow grazers to maintain a higher level of nutrient intake during periods of grass dormancy. The influences of livestock management and cultural practices on forb availability and the grazing animal deserve further study.

\section{Literature Cited}

Cordova, F.J. 1978. Intake and nutritive value of forage grazed by cattle on fertilized and unfertilized blue grama rangeland. Ph.D. Thesis, New Mexico State Univ., Univ. Microfilms. Ann Arbor, Mich. (Diss. Abstr. 38:3971).

Cordova, F.J., J.D. Wallace, and R.D. Pieper. 1978. Forage intake by grazing livestock: A review. J. Range Manage. 31:430-438. 
Ellis, W.C., J.P. Telford, H. Lippke, and M.E. Riewe. 1984. Forage and grazing effects on intake and utilization of annual ryegrass by cattle, $p$. 223-34. In: G.W. Horn (ed.). Natonal Wheat Pasture Symposium Proceedings. Oklahoma Agr. Exp. Sta. Pub. MP-115.

Grovum, W.L. 1984. Integration of digestion and digesta kinetics with control of feed intake - a physiological framework for a model of rumen function, p. 244-268. In: Gilchrist, F.M.C. and Mackie, R.I. (eds.). Herbivore nutrition in the subtropics and tropics. The Science Press, Ltd., Craighall, South Africa.

Helwig, J.T., and K.A. Council. 1979. SAS User's Guide. SAS Institute, Inc., Cary, N.C.

Holechek, J.L., and M. Vavra. 1982. Forage intake by cattle on forest and grassland ranges. J. Range Manage. 35:737-741.

Ingalls, J.R., J.W. Thomas, M.B. Tesar, and D.L. Carpenter. 1966. Relations between ad libitum intake of several forage species and gut fill. $J$. Anim. Sci. 25:283-289.

Kahn, H.E., and C.R.W. Spedding. 1984. A dynamic model for simulation of cattle herd production systems: 2 - An investigation of various factors influencing the voluntary intake of dry matter and the use of the model in their validation. Agr. Sys. 13:63-82.

Kothmann, M.M. 1980. Nutrition of livestock grazing on range and pasture lands, p. 56-90. In: D.C. Church (ed.). Digestive physiology and nutrition of ruminants (2nd ed.). $\mathrm{O}$ and $\mathrm{B}$ Books, Corvallis, Ore.

McCollum, F.T., M.L. Galyean, L.J. Krysl, and J.D. Wallace. 1985. Cattle grazing blue grama rangeland $I$. Seasonal diets and rumen fermentation. J. Range Manage. 38:539-543.

Mertens, D.R., and J.R. Loften. 1980. The effect of starch on forage fiber digestion kinetics in vitro. J. Dairy Sci. 63:1347-1446.

NRC. 1984. Nutrient requirements of domestic animals No. 4. Nutrient requirements of beef cattle (6th ed.). National Academy of SciencesNational Research Council. Washington, D.C.

Owens, F.N., and A.L. Goetsch. 1985. Differential passage and microbial protein synthesis. In: Proc. Int. Symp. on Ruminant Physiology. (In Press).
Pieper, R.D., J.R. Montoya, and V.L. Groce. 1971. Site characteristics pinyon-juniper and blue grama ranges in south-central New Mexico. New Mexico Agr. Exp. Sta. Bull. 573.

Pond, K.R., W.C. Ellis, J.H. Matis, G.T. Schelling, and L.W. Greene. 1982. Compartmental models for estimating gastrointestinal tract fill, flow and output using pulse-dose marker data. J. Anim. Sci. 55 (Suppl. 1): 452.

Poppi, D.P., D.J. Minson, and H. Ternouth. 1980. Studies of cattle and sheep eating leaf and stem fractions of grasses. I. The voluntary intake, digestibility and retention time in the reticulorumen. Aust. J. Agr. Res. 32:99-108.

Rosiere, R.E., J.D. Wallace, and R.D. Pleper. 1980. Forage intake in two-year old cows and heifers grazing blue grama summer range. $J$. Range Manage. 33:71-73.

Short, J.L., R.M. Blair, and C.A. Segelquist. 1974. Fiber composition and forage digestibility by small ruminants. J. Wildl. Manage. 38:197-209.

Thornton, R.F., and D.J. Minson. 1973. The relationship between apparent retention time in the rumen, voluntary intake and apparent digestibil ity of legume and grass diets in sheep. Aust. J. Agr. Res. 24:889-898.

Tilley, J.M.A., and R.A. Terry. 1963. A two-stage technique for the in vitro digestion of forage crops. J. Brit. Grassl. Soc. 18:104-111.

Troelson, J.E., and J.B. Campbell. 1968. Voluntary consumption of forage by sheep and its relation to the size and shape of particles in the digestive tract. Anim. Prod. 10:289-294.

Uden, P., D.E. Colucci, and P.J. Van Soest. 1980. Investigation of chromium, cerium and cobalt as markers in digesta rate of passage studies. $J$. Sci. Food Agr. 31:625-632.

Van Soest, P.J. 1965. Symposium on factors influencing the voluntary intake of herbage by ruminants. Voluntary intake in relation to chemical composition and digestibility. J. Anim. Sci. 24:834-843.

Van Soest, P.J. 1982. Nutritional ecology of the ruminant. O and B Books, Corvallis, Ore.

Varga, G.A., and E.C. Prigge. 1982. Influence of forage species and level of intake on ruminal turnover rates. J. Anim. Sci. 55:1498-1504. 